\title{
Building Brand Loyalty Based Brand Characteristic on Middle Eastern Culinary Msme Products
}

\author{
${ }^{1}$ Moechammad Nasir, ${ }^{2}$ Irmawati, ${ }^{3}$ Shania, ${ }^{4}$ Muzakar Isa, \\ ${ }^{1,2,3,}$ Lecturer, Department of Management Universitas Muhammadiyah Surakarta. \\ ${ }^{4}$ Student, Department of Management, Universitas Muhammadiyah Surakarta. \\ Correspondence : muzakar.isa@ums.Ac.id
}

Received: 06, December, 2021

Accepted: 14, December, 2021

Published: 27 December 2021

\begin{abstract}
This research aims to determine the effect of brand characteristic variables, including brand reputation, brand predictability, and brand competence, on brand loyalty among MSME consumers of the Kak Fiet brand. The research sample was drawn using a non-probability sampling method called purposive sampling. One hundred twenty-seven respondents participated in this research. The data used in this research were primary data collected through questionnaires. Data analysis included validity and reliability tests, classical assumption tests, path coefficient tests, the goodness of fit tests, and hypothesis testing using the SmartPLS program. The results show that 1) brand reputation has a significant effect on brand loyalty; 2) brand predictability has no significant effect on brand loyalty; and 3) brand competence has a significant effect on brand loyalty. It demonstrates that the hypotheses that brand reputation has a significant effect on brand loyalty and that brand competence has a significant effect on brand loyalty are confirmed. In contrast, the hypothesis that brand predictability has a significant effect on brand loyalty is not proven. This means that not all brand characteristic elements have a significant effect on brand loyalty on Kak Fiet MSME products.
\end{abstract}

Keywords: Brand reputation, brand predictability, Brand competence, Brand loyalty

\section{Introduction}

Culinary products from the Middle East and South Asia were historically brought into Indonesia by traders from Yemen, India, and Pakistan during the pre-independence period. These dishes were initially consumed only by immigrants before spreading to the Indonesian population. Today, Indonesians increasingly recognize that country's cuisine is in demand, with a growing market. In its management, the taste of the cuisine is adjusted to the preference of the archipelago. Currently, a number of entrepreneurs of Middle Eastern and South Asian descent, particularly those in the culinary world, are introducing authentic dishes.

Micro, Small, and Medium Enterprises (MSMEs) culinary products from the Middle East and South Asia are now widely distributed in Soloraya, Indonesia. This illustrates that the people of Soloraya are very enthusiastic about the culinary offerings, which are viewed as an opportunity to enjoy delicious food at reasonable prices. In Soloraya, we can find this typical culinary business, such as kebuli, biryani, oily rice, Arabic soup porridge, Indian martabak, chicken curry, or Indian goat curry, selado, sambal, and kopi sendok emas (Monica, 2020).

The growth of the Middle Eastern and South Asian culinary markets has made this business competition even stronger. This condition encourages the owners of this culinary MSME to change their behavior pattern when implementing their business to immediately give a brand name to the culinary products they offer. The "Kak Fiet" brand, founded by a woman of Yemeni and Pakistani ancestry, is one of the SMEs that serves this cuisine. This MSME was founded in Surakarta in 2014 and has since expanded throughout the Soloraya region. This brand specializes in Middle Eastern and South Asian cuisine, using authentic family recipes passed down from generation to generation and premium quality ingredients. Furthermore, the "Kak Fiet" brand manufactures and sells frozen foods popular among Indonesians and their descendants, including Maryam, Sambosa, Pastel, Croquettes, Kebabs, and others.

Brand loyalty is formed by how well a company can satisfy its customers. If the company is able to meet or even exceed consumer expectations, it will have an impact on the level of brand loyalty for the company's products. Consumers will become disloyal to the brand if it does not provide satisfaction; on the other hand, consumers will keep using a brand if they feel satisfied with it (Aacker, 1991: 34).

According to Kotler \& Keller (2012: 138), indicators of brand loyalty include repeat purchases (loyalty to product purchases), retention (resistance to negative influences on the company), and referrals (referencing the total existence of the company). One of the determinants of consumer decisions to be loyal to a brand is that the brand is built based on brand characteristics. These elements play an important role in determining whether or not a consumer trusts a brand, which positively impacts brand loyalty. According to Lau and Lee (1999), business actors must consider brand characteristics, which include three elements: brand reputation, brand predictability, and brand competence, when building brand loyalty.

Brand loyalty is defined as a consumer's psychological commitment to a brand as well as a form of consumer trust in the 
brand through the act of repurchasing a brand product. Consumers will continue to buy and use these product brands on a regular basis, and they will also refuse to use or purchase similar products from other brands (Keller, 2013). Brand loyalty is the commitment to repurchase a particular brand (Peter and Olson, 2003: 129). Brand loyalty also reflects consumers' preference for one brand over others in a given product category (Giddens and Nancy, 2002).

Brand characteristics contribute to a consumer's decision to trust a brand. Just as people judge others before deciding who to befriend, consumers judge brands before deciding whether or not to establish a relationship with a brand (Lau and Lee, 1999).

Brand reputation is something that is dependent on consumers' opinions of the brand, which refers to the opinion of others that the brand is good and reliable, then consumers may trust the brand and be convinced to buy it (Lau and Lee, 2000). Furthermore, a brand with a good reputation gives consumers the impression that the brand is of high quality; the lower the risk, the lower the cost of collecting information before purchasing the products (Erdem et al. 2002 dan Setyawan et al. 2015).

Brand predictability refers to a brand's ability to be anticipated by consumers with complete confidence due to consistent product quality. It results from repeated interactions in which one party makes a promise and keeps it, and others learn more about the brand (Lau and Lee, 2000). Brands create predictability by promising consumers signals, and producers continue to demonstrate brand building (Setyawan et al., 2015). The consumer's ability to predict (with reasonable confidence) the brand's performance in various usage situations is termed brand predictability (Tjiptono, 2014:398)

A brand with brand competence is one that can solve consumer problems while also meeting their needs. A consumer can learn about the competence of a brand through direct use or word-ofmouth communication. Consumers may be willing to rely on a brand once they are convinced that it can solve the problem. In the context of brand trust, consumers will develop a sense of trust based on the brand's ability to meet their needs (Lau and Lee, 2000; and Setyawan et al., 2015).

Research findings show that when consumers are emotionally loyal to a brand, they become attached to the brand and continue to build a strong relationship with it. Furthermore, a brand's presence in a consumer's collection of choices leads to a strong relationship between the customer and the brand (Tsai et al., 2014). As a result, research on Middle Eastern and South Asian culinary products on branded MSMEs in the Soloraya region based on brand characteristics such as brand reputation, brand predictability, and brand competence to build brand loyalty is an extremely important subject to investigate.

\section{Literature Review}

According to Lau and Lee (2000), brand characteristics are important, and its three elements are critical in developing brand loyalty. Belief in a brand is a manifestation of an entity (unity) in which what is trusted is not only the product but a unified symbol. This corresponds to the three entities involved in the brandconsumer relationship: the brand, the company behind the brand, and the consumers who interact with the brand. The study's findings indicate that all three elements of brand characteristics, namely brand reputation, brand predictability, and brand competence, significantly affect brand loyalty.

Grabner et al. (2008) elaborate consumers have a wide range of associations with brands. One type of association is brand influence, which can be defined as a positive or negative consumer evaluation of a brand. As a result, consumers are high risk-averse to the brand, and the brand will provide them with more pleasure in avoiding risk. In general, consumers will feel better when they use the brand. According to the study's findings, customer aversion to risk is significantly associated with two types of loyalty based on the brand characteristic (attitude loyalty and brand loyalty).

Phan and Ghantous (2013) pinpoint that services are frequently associated with a higher perceived risk than goods that can be produced. Perceived risk is typically assessed using two criteria: the uncertainty associated with a person's choice and the consequences of a bad choice. Brand trust is critical in establishing long-term relationships between consumers and the providers of goods or services, with perceived risk. Customer perceptions are measured using brand characteristics, and the results of the study show that personnel-based brand characteristics are the driving force behind brand trust and have a direct impact on brand loyalty.

According to Rampl and Peter (2014), brand characteristics have been shown to explain significant variation in the brand attractiveness of a company's products. Despite widespread awareness, little is known about the underlying mechanisms of this effect. They used product brands that influence consumers and brand trust as a tool to explain the attractiveness of the company's brand, build on brand characteristics, and contribute to better longterm brand loyalty.

Anik and Putri (2015) outline competition in the telecommunications industry is fierce, with each provider striving to be the best in the eyes of consumers. Brand trust is an essential factor in consumer choice when it comes to selecting a brand. The study's findings indicate that brand characteristics have a significant effect on brand loyalty. If brand consumers' characteristics improve, they will become more loyal to the brand. According to the findings of this study, brand characteristics influence 55.70 percent of brand loyalty. According to Setyawan et al. (2015), brand loyalty is part of relationship marketing, so brand loyalty has become an important issue in marketing. Consumer trust in brands is a concept that is strongly linked to the development of brand characteristics in a company's products.

a. The effect of brand reputation on brand loyalty. Leonardo (2013) argues brand reputation has a significant impact on brand loyalty. Furthermore, according to Joshua et al. (2020), brand reputation positively and significantly affects brand loyalty.

H1: Brand reputation has a significant and positive effect on brand loyalty.

b. The effect of brand predictability on brand loyalty. Syeda et al. (2013) acknowledge brand predictability has a positive and significant effect on brand loyalty. Cristiani K (2015) also states brand predictability has a significant impact on brand loyalty.

H2: Brand predictability has a significant and positive effect on brand loyalty

c. The effect of Brand Competence on Brand Loyalty. According to Ermano (2016), brand competence has a significant effect on brand loyalty. It is in line with Shankar et al. (2020), who also agreed that brand competence has a positive and significant effect on brand loyalty.

H3: Brand competence has a significant and positive effect on brand loyalty

\section{Method}


This is quantitative research. The population consisted of all customers of the MSME brand "Kak Fiet" in Solo, Indonesia. The sample was selected using non-probability sampling with the purposive sampling method. This research included 127 respondents as samples. The data used in this research were primary data collected through questionnaires. The measurement scale used was a Likert scale using five intervals (Strongly Disagree, Disagree, Neutral, Agree, and Strongly Agree). Data tests included validity and reliability tests, multicollinearity Classical Assumption tests, and evaluation of inner models using the Smart PLS program.

\section{Results}

The age of the respondents was dominated by people in the age range 21-30 years, with a total of 52 respondents or $41 \%$, followed by the age of 31-40 years, which had $33.8 \%$, the age of $41-50$ years, with a percentage of $19.7 \%$, and the age of 51-60 years, which was $5.5 \%$. The majority of respondents (48 respondents or $37.8 \%$ ) were housewives, followed by students (25.2\%), entrepreneurs $(19.7 \%)$, teachers $(5.5 \%)$, civil servants $(4 \%)$, private employees $(3.1 \%)$, lecturers $(2.3 \%)$, and midwives, doctors, and notaries each at $0.8 \%$. According to the frequency of purchases, 75 respondents or $59.1 \%$ made $1-4$ times purchases, followed by $15.7 \%$ who made more than ten times purchases, $14.2 \%$ who made 5-7 times purchases, and $11 \%$ who made 8-10 times purchases.

\section{A. Validity Test}

1). Convergent Validity

An indicator is declared to be in a good category if the value of outer loading is $>0.7$.

Table1. Outer Loadings

\begin{tabular}{|l|l|l|}
\hline Variable & Indicator & Outer Loadings \\
\hline \multirow{3}{*}{$\begin{array}{l}\text { Brand Reputation } \\
\left.\mathrm{X}_{1}\right)\end{array}$} & BR1 & 0,769 \\
\cline { 2 - 3 } & BR2 & $-0,682$ \\
\cline { 2 - 3 } & BR3 & 0,823 \\
\cline { 2 - 3 } & BR4 & 0,647 \\
\hline \multirow{3}{*}{$\begin{array}{l}\text { Brand Predictability } \\
\left.\mathrm{X}_{2}\right)\end{array}$} & BR5 & 0,649 \\
\hline & BP1 & 0,871 \\
\cline { 2 - 3 } & BP2 & 0,792 \\
\cline { 2 - 3 } & BP3 & 0,815 \\
\hline & BP4 & 0,781 \\
\hline Brand Competence & BP5 & 0,838 \\
\hline$\left(\mathrm{X}_{3}\right)$ & BC1 & 0,775 \\
\hline & BC2 & 0,771 \\
\hline & BC3 & 0,855 \\
\hline & BC4 & 0,753 \\
\hline \multirow{2}{*}{$\begin{array}{l}\text { Brand Loyalty } \\
\text { Y) }\end{array}$} & BC5 & 0,811 \\
\hline & BL1 & 0,619 \\
\hline & BL2 & 0,795 \\
\cline { 2 - 3 } & BL3 & 0,813 \\
\cline { 2 - 3 } & BL4 & 0,841 \\
\hline & BL5 & 0,728 \\
\hline & BL6 & 0,780 \\
\hline
\end{tabular}

Source: Primary data, 2021

The outer loading of each research variable is greater than 0.6. Individual reflexive measures are said to be high if they correlate with the construct being measured by more than 0.7 . According to Widiyastuti and Pamudji (2009) and Ghozali (2006), a loading factor value of 0.5 to 0.6 is adequate and can be maintained.

\section{2) Discriminant Validity}

Average Variant Extracted (AVE) is used to determine discriminant validity for each indicator that has a criterion of $>0.5$ to be considered valid.

\section{Table 2 Average Variant Extracted (AVE)}

\begin{tabular}{|l|l|l|}
\hline $\begin{array}{l}\text { Construct Reliability } \\
\text { and Validity }\end{array}$ & $\begin{array}{l}\text { Average Variance } \\
\text { extracted (AVE) }\end{array}$ & Keterangan \\
\hline Brand Reputation & 0,527 & Valid \\
\hline Brand Predictability & 0,672 & Valid \\
\hline Brand Competence & 0,630 & Valid \\
\hline Brand Loyalty & 0,588 & Valid \\
\hline
\end{tabular}

Source: Primary data, 2021

The AVE value of brand reputation is greater than 0.5 or 0.527 , while for brand predictability, brand competence, and brand loyalty are $0.672,0.630$, and 0588 , respectively. This demonstrates that each variable has good discriminant validity.

\section{B. Reliability Test}

1) Composite Reliability. Variables are said to meet composite reliability if their Composite Reliability value is greater than 0.7 (Value > 0.7)

Table 3 Composite Reliability

\begin{tabular}{|l|l|l|}
\hline $\begin{array}{l}\text { Construct Reliability } \\
\text { and Validity }\end{array}$ & $\begin{array}{l}\text { Composite } \\
\text { Reliability }\end{array}$ & Description \\
\hline Brand Reputation & 0,815 & Reliable \\
\hline Brand Predictability & 0,911 & Reliable \\
\hline Brand Competence & 0,895 & Reliable \\
\hline Brand Loyalty & 0,894 & Reliable \\
\hline
\end{tabular}

Source: Primary data, 2021

The brand reputation variable has a Composite Reliability value of 0.815 , the brand predictability variable has a value of 0.911 , the brand competence variable has a value of 0.895 , and the brand loyalty variable has a value of 0.894 , all of which are greater than 0.7. The Composite Reliability value for each variable with a magnitude greater than 0.7 indicates that the four variables are reliable.

2) Cronbach Alpha. The reliability test with Composite Reliability above can be strengthened by using Cronbach's Alpha value. A variable can be said to be reliable if it has a Cronbach Alpha value $>0$.

Table 4 Cronbach's Alpha

\begin{tabular}{|l|l|l|}
\hline $\begin{array}{l}\text { Construct Reliability } \\
\text { and Validity }\end{array}$ & Cronbach's Alpha & Description \\
\hline Brand Reputation & 0,698 & Not Reliable \\
\hline Brand Predictability & 0,878 & Reliable \\
\hline Brand Competence & 0,853 & Reliable \\
\hline Brand Loyalty & 0,859 & Reliable \\
\hline
\end{tabular}

Source: Primary data, 2021

Cronbach's Alpha for brand reputation is 0.698 , less than 0.7 , while the values for brand predictability, brand competence, and brand loyalty are $0.878,0.853$, and 0.859 respectively, which are all greater than 0.7. As a result of these findings, it is possible to conclude that almost all variables have a high level of reliability, with the exception of the brand reputation variable, which did not meet the requirements of Cronbach's Alpha.

\section{Multicollinearity Test}

The results of Collinearity Statistics (VIF) of the brand reputation variable on brand loyalty are 3,367 . Then the brand predictability 
variable has a value of 4.762 on brand loyalty. The brand competence variable has a value of 5.351 on brand loyalty. From these results, the VIF value is $<10$. Then the brand reputation, brand predictability, and brand competence variables do not fail the multicollinearity assumption test.

\section{The Results of Path Coefficient Test}

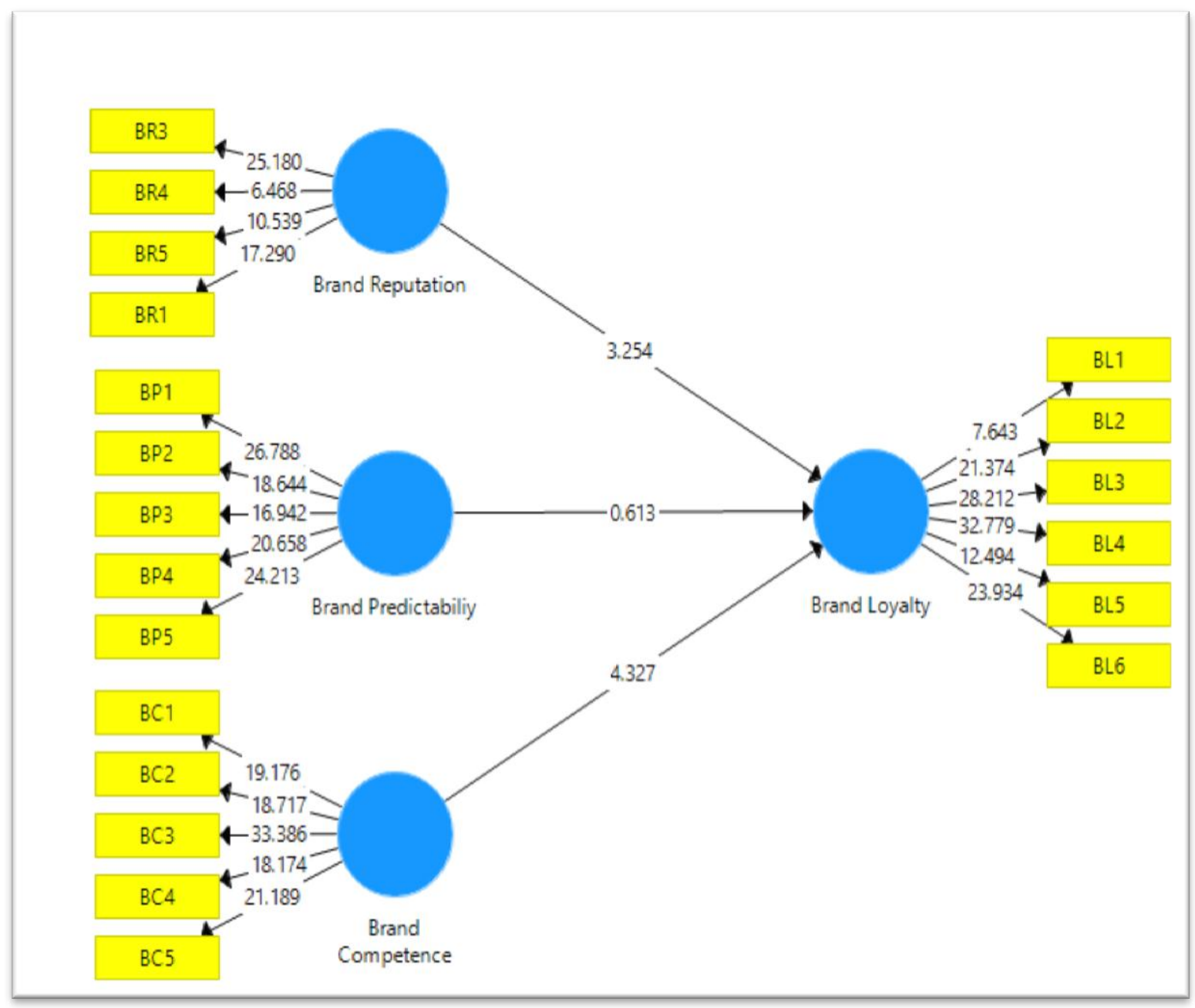

Figure 1. Inner weight

The influence of brand competence on brand loyalty has the highest path coefficient of 4.327 . The second biggest effect, with a value of 3.254 , is the influence of brand reputation on brand loyalty. The influence of brand predictability on brand loyalty has the smallest effect of 0.613. All variables in this model have a positive path coefficient. This demonstrates that the stronger the influence of the independent variables on the dependent variable, the greater the path coefficient value of one independent variable on the dependent variable.

\section{E. The Results of the Goodness of Fit Test}

F.The Results of Hypothesis Testing

Table 7 Inner Weights Values

\begin{tabular}{|l|l|l|l|l|l|l|}
\hline Path Coefficients & $\begin{array}{l}\text { Original } \\
\text { Sample }\end{array}$ & $\begin{array}{l}\text { Sample } \\
\text { Mean }\end{array}$ & $\begin{array}{l}\text { Standard } \\
\text { Deviation }\end{array}$ & $\begin{array}{l}\text { t } \\
\text { Statistics(Ts) }\end{array}$ & $\begin{array}{l}\text { P } \\
\text { Values }\end{array}$ & Description \\
\hline Brand Reputation $\rightarrow$ Brand Loyalty & 0,292 & 0,302 & 0,096 & 3,048 & 0,002 & Positive-Significant \\
\hline Brand Predictability $\rightarrow$ Brand Loyalty & 0,068 & 0,060 & 0,117 & 0,585 & 0,559 & Positive-Not significant \\
\hline Brand Competence $\rightarrow$ Brand Loyalty & 0,522 & 0,526 & 0,122 & 4,286 & 0,000 & Positive-significant \\
\hline
\end{tabular}

Table 6 R Square

\begin{tabular}{|l|l|l|}
\hline R Squares & & \\
\hline & R Squares & R Adjusted \\
\hline Brand Loyalty & 0,708 & 0,723 \\
\hline
\end{tabular}

Source: Primary data, 2021

The influence of brand reputation, brand predictability, and brand competence on brand loyalty is 0.708 or $70.8 \%$. As a result of these findings, this research model can be declared to have good goodness of fit.

\section{Discussion}


research, brand reputation has a positive and significant influence on brand loyalty. Those findings are consistent with the findings of the research, which show that brand reputation has a positive and significant impact on brand loyalty. Furthermore, the findings of Syeda et al. (2013) and Cristiani K (2015), which state that brand predictability has a positive and significant effect on brand loyalty, differ from the findings of this research, which show that brand predictability has a positive and significant effect on brand loyalty. Finally, research by Ermano (2016) and Shankar et al. (2020), which state that brand competence has a positive and significant influence on brand loyalty, support this research, namely that brand competence has a positive and significant influence on brand loyalty.

\section{Conclusion}

The findings of this research reveal that brand reputation and brand competence have a positive and significant effect on brand loyalty, whereas brand predictability has a positive but not significant effect on brand loyalty. As a result, MSME business managers' marketing strategy is to strengthen the brand's reputation through quality improvement based on consumer expectations, increase product competence through increasing the reliability of product taste, service improvement, and product availability, and expand its business through increasing the variety of products offered.

\section{Conflicts of Interest}

This research is a quantitative research. The data used in this research were primary data collected through questionnaires. The researcher states that there is no conflict of interest related to the publication of this article, this is because the data is a consumer perception of the brand of a business.

\section{Funding Statement}

The source of funds for the implementation of this research and the publication of research results came from the individual lecturer development fund (PID) program that managed by the Faculty of Economics and Business, University of Muhammadiyah Surakarta.

\section{Acknowledgments}

We want to thank Universitas Muhammadiyah Surakarta for providing financial support to this study. In addition, we would also like to extend our gratitude to reviewers for their helpful comments and suggestions.

\section{References}

[1] Anik, S., and. P. Putri. 2015.Influence of Trust in a Brand to Brand Loyalty on Consumer Provider Smart Telecom. Global Journal of Emerging Trends in eBusiness Marketing and Consumer Psychology (GJETeMCP). 1 (1): 208 - 222.

[2] Bahoosh, K., Alvani, S.M., Vaezi, R. 2004. Identification and Prioritization of Factors Affecting Customer Satisfaction and Their Relation with Loyalty in Branches of Eghtesad Novin Bank Throughout Tehran. Arabian Journal of Business and Management, 251-264.

[3] Darwin, Steven dan Kunto, Yohanes Sondang. Analisis Pengaruh Kualitas Layanan terhadap Loyalitas Pelanggan dengan Kepuasan dan Kepercayaan sebagai Variabel Intervening pada assuransi Jiwa Manulife Indonesia - Surabaya. Jurnal Manajemen Pemasaran Petra, Vol. 2 No. 1, 2014.
[4] Dulkhatif, Andi Tri Haryono, dan Moh Mukeri Warso. 2016. "Pengaruh Kualitas Pelayanan, Kepuasaan Pelanggan dan Lokasi terhadap Pelanggan pada Penyedia Jasa Internet Study PT NOKEN MULIA UTAMA Semarang", Jurnal of Management, Volume 2 No. 2 Maret 2016

[5] Ermano (2016), dan penelitian Shankar et al., (2020), How Brand Knowledge And Relationships Affect Current And Future Purchases, Journal of Product \& Brand Management. Emerald Group Publishing Limited [ISSN 1061-0421][DOI 10.1108/10610420610658938]. 15(2): 98-105.

[6] Ferdinand, Augusty. 2012. Metode Penelitian Manajemen Pedoman Penelitian untuk Penulisan Skripsi Tesis dan Disertai Ilmu Manajemen Edisi 5. Semarang: Badan Penerbit Universitas Diponegoro

[7] Ghozali, Imam. 2018. Aplikasi Analisis Multivariate Dengan Program IBM SPSS Edisi 25. Semarang: Badan Penerbit Universitas Diponegoro

[8] Funder, J., and D. Morgan. 2015. Desk Research Report, For European National Brand Associations And Aim. Co-ordinated By British Brands Group.

[9] Griffin, J. (2002). Customer Loyalty: How To Earn It How To Keep It. Foreward By General Robert T. Herres. ISBN 0-7879-6388-7 (alk Paper). The United States Of America. Second Edition. PB Printing.

[10] Isa, M. and Mangifera, L. 2019. Continuous flood risk reduction on MSMEs: Implementation of MACTOR program. Economic Journal of Emerging Markets, 11(1) 2019, 113-121

[11] ISA, Muzakar. Strengthening Institutional Capacity of Guitar Cluster: Implementation of DEA and MACTOR. Ekuilibrium : Jurnal Ilmiah Bidang Ilmu Ekonomi, vol. 16, no. 2, p. 107-116, oct. 2021. ISSN 2528-7672. doi:http://dx.doi.org/10.24269/ekuilibrium.v16i2.3488.

[12] Isa, M., Wajdi, M. F., Mabruroh, Nurhayati, S.F., Kamarulzaman, N.H., 2021. Sustainability of Rice Business in Flood-Prone Areas. Environmental Research, Engineering and Management. Vol. 77 No. 4 (2021). DOI: https://doi.org/10.5755/j01.erem.77.4.28096

[13] Kemp, E., dan M. Bui. 2011. Healthy Brands: Establishing Brand Credibility, Commitment, and Connection Among Consumers. Journal of Consumer Marketing. Emerald Group Publishing Limited [ISSN 0736-3761]. 28(6): 429-437.

[14] Lau, G. T., dan S. H. Lee. 2000. Consumers' Trust in a Brand and the Link to Brand Loyalty, Journal of Market Focused Management. Kluwer Academic Publishers. Boston. Manufactured in The Netherlands. 4: 341-370.

[15] Liu, C. T., Guo, Y. M., and Le, C. H. 2011. The effects of relationship quality and switching barriers on Customs loyalty. International Journal of Information Management. 31: 71-79.

[16] Leonardo (2013), Brand Characteristics to Brand Loyalty, Journal of Marketing Academic Publishers. Boston. Manufactured in The Netherlands. 8: 251-270.

[17] Liu, C. T., Guo, Y. M., and Le, C. H. 2011. The effects of relationship quality and switching barriers on Customs loyalty. International Journal of Information Management. 31: 71-79.

[18] Mangifera, L., Isa, M.,Wajdi, M.F., 2018. Analisis Faktor-Faktor Yang Mempengaruhi Wisatawan Dalam Pemilihan Kuliner Di Kawasan Wisata Alam Kemuning Daya Saing. Jurnal Ekonomi Manajemen Sumber Daya Vol. 20, No. 1, Juni 2018 
[19] Parasuraman, A. Et al. 2008. Delivering Quality Service: Balancing Customer Perceptions and Expectations. USA: The Free Press Collier Macmillan Publisher

[20] Robinette, S and Brand C. 2009. Emotion Marketing: The Hallmark Way of Winning Customers for Life. New York: The Free Pass

[21] Sangadji, Etta Mamang dan Sopiah. 2013. Perilaku Konsumen: Pendekatan Praktis disertai Himpunan Jurnal Penelitian. Edisi 1. Yogyakarta: ANDI.

[22] Sekaran, Uma dan Bougie, Roger, 2017. Metode Penelitian Bisnis. Edisi enam buku 1. Terjemah oleh Kwan Men Yon.Jakarta: Salemba empat.

[23] Sholihin, M. \& Ratmono, D. (2013). Analisis SEM-PLS dengan WarpPLS 3.0 un tuk hubungan non liner dalam penelitian sosial dan bisnis. Yogyakarta: Andi

[24] Sugiyono. 2015. Metode Penelitian Kombinasi (Mix Methods). Bandung: Alfabeta
[25] Syeda et al. (2013) dan Cristiani K (2015), Brand Competence and Customer Loyalty: Sustainable Malaysian SME Brands Study.Asian Social Science ISSN 1911-2017 E-ISSN 1911-2025. Published by Canadian Center of Science and Education. 11(26): 252266.

[26] Tengku Putri Lindung Bulan. 2016. "Pengaruh Kualitas Pelayanan dan Harga terhadap Loyalitas Konsumenn pada PT. Tiki Jalur Utama Ekakurir Agen Kota Langsa”. Jurnal Manajemen dan Keuangan, Vol.5, No.2, November 2016

[27] Yoshua et al., (2020), The Effects Of Brand Credibility On CustomersWom Communication: The Mediating Role Of Brand Commitment, European. Journal of Business and Social Sciences. ISSN: 2235-767X. 4( 09): 164-176. 